\title{
Psychographic Factors Influence Saudi Consumer's Service Quality in Hypermarket
}

\author{
Dr. Naif Mutlaq Al Otaibi \\ Othman Yeop Abdullah Graduate School of Business \\ Universiti Utara Malaysia
}

Kausar Yasmeen (Corresponding author)

Universiti Utara Malaysia

Email: eco.yasmeen@gmail.com

DOI:10.5296/ ijld.v4i4.6660 URL: http://dx.doi.org/10.5296/ ijld.v4i4.6660

\begin{abstract}
With a robust economic growth and a young population, Saudi Arabia has witnessed a high consumer demand in the food and grocery sector. This has led towards a transformation of its retailing industry from small and unorganised markets to palatial malls and hypermarkets. As the number of choices increases with the entry of new players, retailers need to understand customers' perceptions of the quality of services and product offered as this is crucial towards the survival and competitiveness in the market. The determinants of service quality vary across different industries, countries and individual characteristics. However, studies that link customer service to factors such as demographic, psychographic characteristics are scarce especially in this region. Therefore, the primary goal of this research is to examine the influence of perceived service quality on customer's living style and demographic variables. In carrying out this research, questionnaires were distributed to retail customers in major shopping malls located in three cities which represent more than $60 \%$ of the Saudi population (Riyadh, Jeddah, and Dammam). 800 questionnaires were distributed but only 408 questionnaires were useable, yielding a response rate of $51 \%$. The findings revealed that the two antecedent factors demographic had a partial influence on PSQ while psychographic has no influence. The study concluded with some recommendations that can be of a great use to retailers in Saudi Arabia and future researchers.
\end{abstract}

Keywords: Perceived service quality, psychographic, Grocery Retailing, Saudi Arabia, Middle East, Golf countries 


\section{Introduction}

The Saudi grocery retail market has recently been characterized by a shift from local traditional grocery shops to a large number of hypermarkets and malls distributed throughout the country whether these malls are local Saudi malls or as a result of foreign investment (GCC, 2012). There are numerous factors that contribute to the growing number of malls and hypermarkets in Saudi Arabia such as the dramatic increase in the country's population, improved education, changing shopping habits where customer's expectations are changing and growing and the urbanization of the country's rural areas in which statistics revealed that $82 \%$ of the population live in urban areas in 2010 (Business Monitor International, 2012). But, despite the widespread establishment of hypermarkets and malls all over the country, the statistics revealed that Saudi consumers still prefer to do their grocery shopping activities in traditional and small markets and convenience stores. This contradicts the previous fact that $82 \%$ of the population live in urban areas which are characterized by a vast availability of hypermarkets where many sections are provided for the ease of grocery shopping (Othaim, 2012). In this context, the GRDI Report (2010) indicates that traditional grocery retailing remains dominant in Saudi Arabia which has contributed to $51 \%$ of sales value in 2010. This claim is also supported by Retail ME Report (2012) which indicates that most grocery retail services at present are still served by small local groceries. Another report predicts that traditional stores would represent 59\% of retail market in Saudi Arabia in 2013 (Al Rajhi Capital, 2013). Indeed, statistical report of Saudi Ministry of Municipal and Rural Affairs 2010 revealed that the retail sector in the Saudi market is fragmented which is characterised by the dominance of sales in individual stores (ACG, 2009; AlGhamdi, Drew, \& Waleed, 2011).

Furthermore, most researches on the grocery retail industry have been conducted in Western or even Eastern countries while the research conducted on such aspect in developing countries like the Middle East and Saudi Arabia in particular (AlGhamdi, Drew \& AlGhaith, 2011; Yang \& Jolly, 2009) is few. AlGhamdi et al. (2011) recommended that further research should be conducted on grocery retail in Saudi Arabia and on customers' perceptions towards the services provided by grocery retailers. Thus, understanding the perceived service quality construct and the variables affecting its provision are grounded studies from Western perspective. As a result, such insight might be of limited use to Saudi retailers due to cultural and behavioural differences (Rahman, 2012).

In addition, studies that link customer service to factors such as demographic and psychographic characteristics as well as the store format choice are rather limited in spite of the finding that individual consumer characteristics can influence their shopping behaviour (Baltas \& Argouslidis, 2007; Carpenter \& Moore, 2006; Fox et al., 2004; Medina \& Ward, 1999). (McCarthy, 2011; Monroe, 2003) It is asserted that demographic and psychographic characteristics of customers affect the choice of benefits they want and the importance of these benefits as well as their willingness to pay for them. Thus, it is essential for retailers to recognize the factors that influence the perceived service quality by customers by taken the demographic and psychographic characteristics into account so that they can direct their marketing strategies and services to ensure a favourable impression of service quality. 
However, this study contributes in term of policy making, marketing area and for the investor.

\section{Literature Review}

\section{Relationship between Consumers' Demographic Factors and Perceived Service Quality}

Literature indicates that perception about quality with regards to value delivered by a service outlet is influenced by individual characteristics of consumers. The demographic profiles of the customers such as sex, age, marital status, level of education, income and the number of family members were found to have a strong influence on their perceived service quality of grocery store (Carpenter \& Moore, 2006; Dedic \& Pavlovic, 2011; Sinha \& Banerjee, 2004; Swaid, 2009). Sinha (2003) conducted a study to examine the impact of individual characteristics on perceived service quality in the retail market. He found that perceived service quality was related to customer satisfaction and loyalty. $\mathrm{He}$ also revealed that those consumers' individual characteristics such as age, gender; income and family size had a significant impact on consumers' perceived service quality. Therefore, given the effect of individual characteristics on consumers' perception of service quality, it is posited that:

\section{Relationship between Geographic Factors and Perceived Service Quality}

Generally, the nearer customers are to a particular retail outlet, the higher their tendency to buy from that outlet. On the other hand, as the distance between the customers and the shop increases, the more choices the consumer are provided with but it is less likely for the consumer to patron a shop that is far from his/her residential location (Clifton, Muhs, Morrissey, Morrissey, Currans, \& Ritter,2012). The time it takes to go to the store is a reflection of the total effort, both physical and psychological, to arrive at the retail store. Accessibility or location vicinity of a retail store site measures the level of comfort with reference to the shopping trip and hence it symbolizes a major attribute of a retail service quality attribute from a customer's perspective (Alzubaidi, Vignali, Davies, \& Schmidt, 1997; Manu, 2011). For example, shopping outlets that provide easy access to their outlets which in turn allow the customers to get there with ease and comfort will score better in terms of tangibility, which is one of the main dimensions of perceived service quality. The case is same for shopping outlets that provide enough parking lots for customers to park their vehicles. In addition, shopping outlets that select their locations in less crowded parts of the city will more likely influence consumers' perceptions about the ease of travel, which is also a dimension in the construct of geographical factor (Elias, Lydia, \& Cleophas, 2012). Therefore, based on these arguments, the following hypothesis is postulated:

\section{Relationship between Consumers' Psychographic Factors and Perceived Service Quality}

Previous researches have made efforts to segment customers according to their values and life styles (Grunert, Brunso, \&Bisp, 2011; Huang, 2014), activities, interests and opinions (Hassan, Muhammad, \& Bakar, 2010). For instance, the total variety of merchandise and services used by a consumer was a reflection image of his/her life using AIO (activities, interests and opinions) factors. Nijmeijer et al. (2004) investigated the association between food lifestyle and vegetable consumption using personal values, lifestyle components, food beliefs and attitudes. In their study conducted in the USA, Krishnan (2011) revealed that 
psychographic factors (activities, interests and opinions) influenced the perception of service quality of retail outlets. Hence, the following hypotheses are presented from the aforementioned discussion:

\section{Measurement of demographic and psychographic variables}

Present studies have demonstrated that factors relating to the demographic profiles of the customers such as sex, age, marital status, level of education, income and the number of family members pose a strong effect on their choice based on perception of service quality of grocery retailing particularly the store format (Bawa \&Ghosh, 1999; Carpenter \& Moore, 2006; Fox et al., 2004; Sinha \& Banerjee, 2004). Therefore, demographic characteristics that represent the customer background such as age, gender, marital status, education, income and family size (Burke, 2002) were included. The measurement of this factor was adopted from Prasad and Aryasri (2011).

In addition to demographic factors, geographic factors also have an influence on perception about quality and choice of retail store. The shorter the distance between the location of the store and the residential area of the consumers, the greater are their potentials to purchase from that particular store. The higher the likelihood of alternatives, the lower the likelihood of that store being chosen (Karlsson, 2012). Customers who purchase their products at the retail shop have to get over spatial and time distances between where they begin their journey (e.g., residential or work place) and the store outlet (Huff, 1963; 1964; Ingene, 1984). Accessibility of a retail shop site means the level of comfort regarding this purchasing encounter, which symbolizes a significant attribute of a retail shop agglomeration from the customer's perspective (Alzubaidi et al., 1997; Manu, 2011). The measurement for geographic location was adopted from Wilson, Alexander, \& Lumbers (2004).Wilson, Alexander, \& Lumbers (2004) used three items to measure the geographical factor and these three items refer to three dimensions, namely distance, time and ease of travel. In this study, only two items were adopted from the researchers' study and these items are distance and ease of travel. The third item (time) was not included as this item itself refers to distance and easiness and thus there was no need for repetition.

Psychographics is a method used to determine and evaluate the way of life of customers using their activities, interests and opinions (Tam \& Tai, 1998; Larsen, 2010). Psychographics measures how the customer's thoughts dictate their perception, feeling and responses (Roy \& Goswami, 2007). In the current study, the psychographic characteristics were measured based upon the customers' activities, interests and opinions (Goswami, 2007), which are likely to influence their needs, motives, perceptions and lifestyles. The measurement of psychographics was adapted from various sources. While values related items were taken from Kotler and Keller (2009), interest and opinion items were taken from VALS Survey (Gonzalez, Fernandez, \& Bello, 2002; Kelly, 2004; Wu, 2003). The construct pertaining to psychographic factors comprise 18 items.

All questions measuring the antecedent factors. Open-ended or closed-ended questions were used to ask demographic and geographic factors. A five-point Likert scale was used on questions measuring psychographic factors. 


\section{Methodology and data description}

\section{Research Framework}

In the previous chapter, a discussion of the $\mathrm{CAB}$ (Cognition Affect Behaviour) model and means-end theory that underpin the current research was offered. To recap, in the CAB model, it is argued that a consumer's evaluation of certain merchandises or services influences his/her affective evaluation, which leads to specific behaviour. The model can be understood from a practitioner's point of view where consumers are seen as seeking utilitarian benefits and possession and purchase of merchandises, service and information are the major objectives of consumer behaviour. This is considered as rational characteristics. In contrast to the practitioners' view, the consumers' perspectives postulate shopping behaviour as involving both rational and irrational aspects. The irrational shopping elements include emotional, sensory and physiological factors. For consumers, the act of shopping is not identical to purchasing. Rather, it is the accomplishment of diverse needs and wants through multiple processes. Therefore, shopping is not merely concerning merchandises and services but also concerning encounters during the buying process. In other words, from the consumers' view, the $\mathrm{CAB}$ model reveals the significance of shopping encounter of consumers and claims that consumer's behaviour is a result of delivering value to the consumers which can be made possible by offering superior service quality. This consumer-focused view acknowledges not only the consequence of the shopping encounter but the overall quality perception and value of market place encounter to consumer as well.

In addition to the CAB model, means-end theory introduced by Gutman (1982) can explain consumer encounter in purchasing behaviour by emphasizing the relationship between consumers' values and merchandise selections (Reynolds \&Gutman, 1988). In other words, means-end theory attempts to portray a link between certain objects attributes or behaviours as the means and the result or effect of the merchandise use, as well as personal values which are significant to an individual.

As the end, this formation of the link from features to end results and from consequences to personal values characterizes a unique configuration called a Means-end chain (Gutman, 1982). This theory was further extended by Bagozzi (1992) who proposed that customer values are formed by their perceptions of service quality (PSQ), which lead to an emotional response that would stimulate the behaviour (Dai \& Salam, 2011). The adaptation of Bagozzi's (1992) model to a service perspective suggests that cognitively-oriented service quality and value appraisals precede satisfaction (e.g., Kim, 2011; Chenet et al., 1999; Dai \& Salam, 2011; Hutchinson, Lai, \& Wang, 2009; Patterson \& Spreng, 1997; Woodruff, 1997). In the field of customer's service quality perception, numerous research studies have utilized PSQ as the key factor which leads to satisfaction and ultimately, customer loyalty.

Based on the models, theories and literatures discussed in the preceding chapter, a research framework is developed, as shown in Figure 3.1. This framework elaborates the antecedents of perceived service quality. 


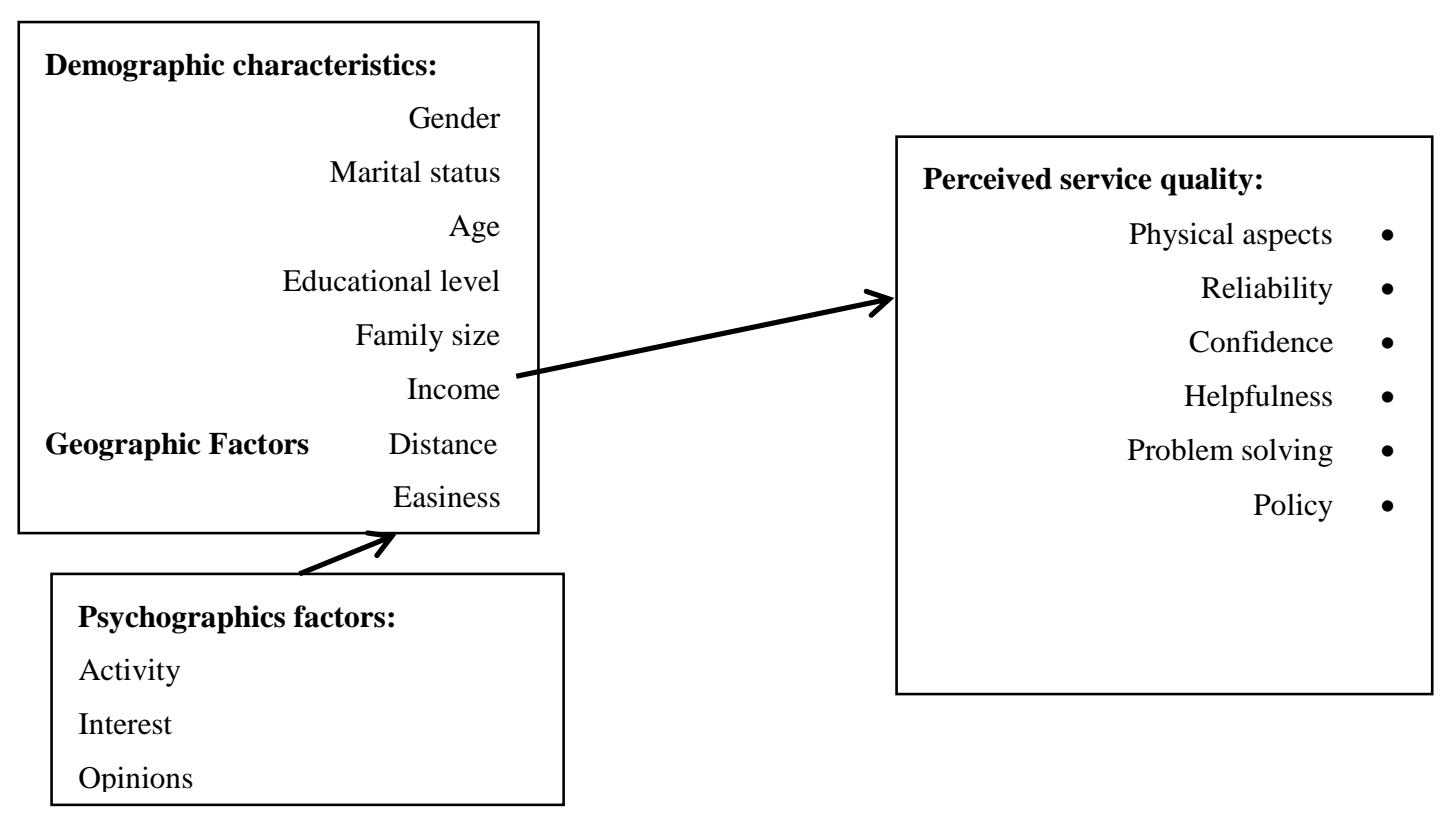

Figure 1

\section{Research framework}

Figure 1 shows how demographic characteristics, socio-economic class, geographic factors and psychographic factors influence perceived service quality. Perceived service quality is measured by facets like physical aspects, reliability, confidence, helpfulness, problem solving and policy.

\section{Data collection}

By adopting the sample method of Bryman and Bell (2003), 408 customers were selected to collect cross sectional data from the major shopping malls (Hyper Panda, Carrefour, Tamimi, Othaim, and Danube) located in three cities (Riyadh, Jeddah and Dammam) of Saudi Arabia. These cities were selected as they represent more than $60 \%$ of the population residing in Saudi Arabia.

\section{Results and discussion}

\section{Demographic Factors and Perceived Service Quality}

To test the hypothesis regarding the demographic factors, an analysis technique that is referred as the dummy variable (sometimes referred to as an indicator variable) was used. A dummy variable usually takes a numerical value ' 0 ' or ' 1 ' to indicate absence or presence of a particular discussion. Having achieved the normality of the error terms assumption, this study further tested for the assumption of linearity, homoscedasticity and independence of the error terms, as discussed below.

In the present study, the dummy variable was applied to the demographic factors. Specifically, in the gender factor, value ' 1 ' was given for male respondents while ' 0 ' was given for female respondents. As for the marital status factor, value ' 1 ' was given to married respondents while 
' 0 ' for unmarried ones. As for the age factor, value ' 1 ' was given to respondents who were 44 years old or below while ' 0 ' was given for those who were 45 years old and above. For the level of education, value ' 0 ' was given for those who had undergraduate degree, while ' 1 ' to those who had Master and $\mathrm{PhD}$ degrees. For the monthly income factor, those who received a monthly income of SR15, 000 and below were given ' 0 ' value whereas ' 1 ' was given to those who earned more than SR15,000. As for family size, value ' 1 ' was given to respondents with 7 family members and below while value ' 0 ' was given to respondents with more than 7 members. Finally, as for the geographical factor, two dimensions were used, namely distance and ease. For the distance dimension, value ' 1 ' was given to those whose trip to the shopping mall is $7 \mathrm{~km}$ and below while value ' 0 ' was given to those whose trip to the shopping mall is above $7 \mathrm{~km}$. As for the easiness dimension, value ' 0 ' was given to not easy while value ' 1 ' was given to easy.

In addition, an attempt was made to divide the hypothesis into a number of sub-hypotheses which are: H1a for gender, H1b for marital status, H1c for age, H1d for education level, H1e for monthly income and H1f for family size. Thus, the main hypothesis regarding the demographic factors and their sub-hypotheses were developed as follows:

Hypothesis 1: There is a positive relationship between demographic factors and perceived service quality.

H1a: There is a positive relationship between gender and perceived service quality.

H1b: There is a positive relationship between marital status and perceived service quality.

H1c: There is a positive relationship between age and perceived service quality.

H1d: There is a positive relationship between education level and perceived service quality.

H1e: There is a positive relationship between monthly income and perceived service quality.

H1f: There is a positive relationship between family size and perceived service quality.

To test the hypotheses, multiple regressions were conducted as explained in chapter three. The results of the regression analysis are displayed in Table 1. The result shows that H1c, H1e, and H1f were supported, while the other sub-hypotheses were not supported. Overall, the main hypothesis (H1) appears to be partially supported. 
Table 1

Effect of Demographic Variables on Perceived Service Quality

\begin{tabular}{|c|c|c|c|c|}
\hline Hypotheses & Variables & Standardized & t value & $p$ value \\
\hline & \multicolumn{4}{|c|}{ coefficients } \\
\hline \multicolumn{5}{|c|}{ beta } \\
\hline H1a & Gender & 0.043 & 0.798 & .425 \\
\hline $\mathrm{H} 1 \mathrm{~b}$ & Marital Status & -0.061 & -1.243 & .215 \\
\hline $\mathrm{H} 1 \mathrm{c}$ & Age & $0.175 * * *$ & 3.310 & .001 \\
\hline H1d & Educ Level & -0.06 & -1.080 & .281 \\
\hline H1e & Monthly Income & $0.133^{*}$ & 1.481 & .070 \\
\hline \multirow[t]{5}{*}{ H1f } & Family size & $-0.144 *$ & -1.707 & .045 \\
\hline & R Square & & & 0.05 \\
\hline & Adjusted R Square & & & 0.022 \\
\hline & F Value & & & 1.821 \\
\hline & F Value Sig & & & 0.049 \\
\hline
\end{tabular}

$* * * p<0.01 ; * * p<0.05 ; * \mathrm{p}<0.10$

\section{Geographical Factors and Perceived Service Quality}

To test the hypothesis regarding the geographical factor (H2), two sub-hypotheses were developed. They are $\mathrm{H} 2 \mathrm{a}$ for distance and $\mathrm{H} 2 \mathrm{~b}$ for ease of travel, as shown below:

Hypothesis 2: There is a positive relationship between geographical factors and perceived service quality.

H2a: There is a positive relationship between distance and perceived service quality.

H2b: There is a positive relationship between easy of travel and perceived service quality.

Multiple regressions were conducted in testing the hypotheses as explained in chapter three. 


\section{Macrothink}

International Journal of Learning \& Development

The results of the regression analysis are depicted in Table 2 and it revealed that only $\mathrm{H} 2 \mathrm{~b}$ was supported. Overall, the main hypothesis (H2) appears to be partially supported.

Table 2

Effect of Geographical Variables on Perceived Service Quality

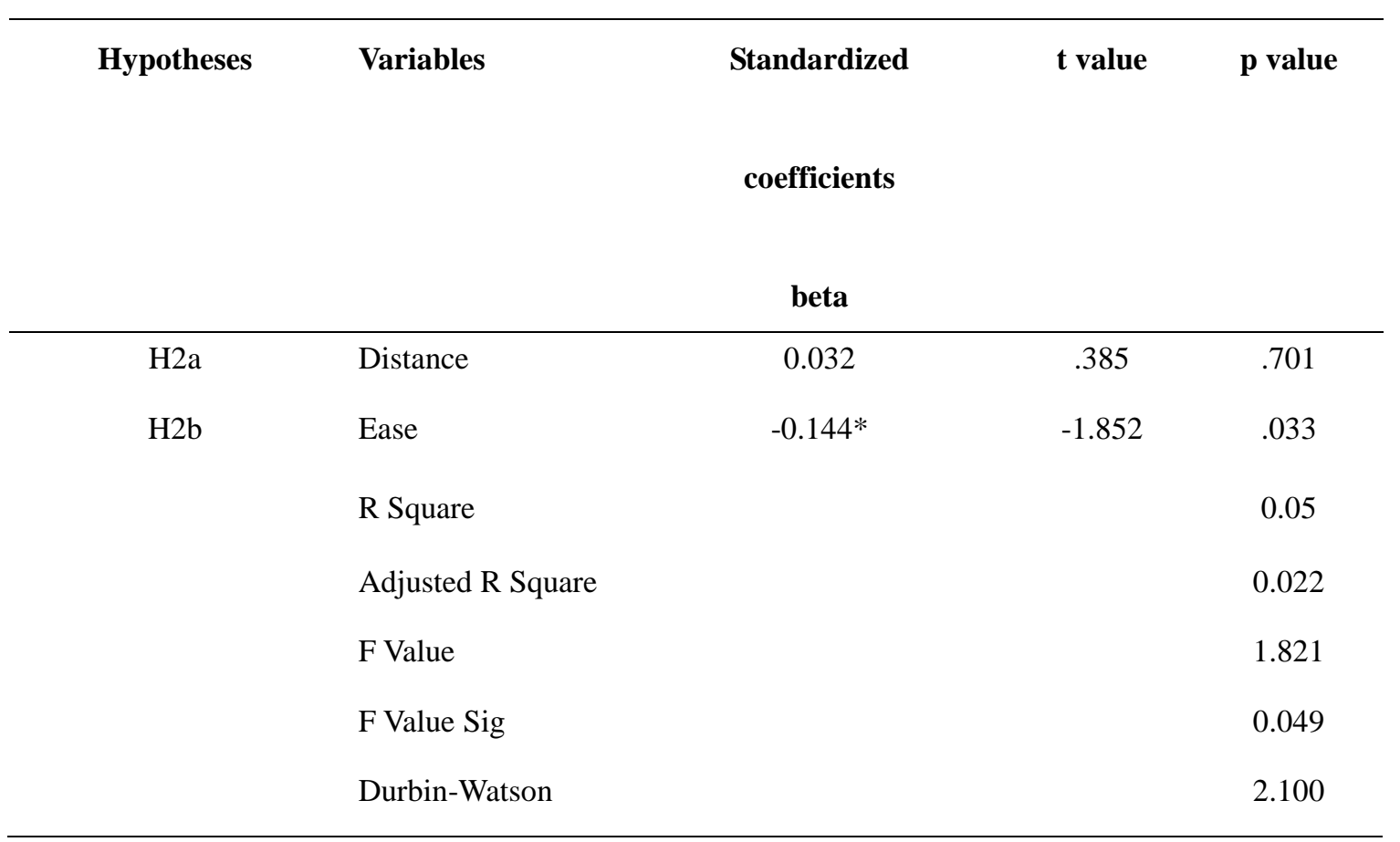

$* * * \mathrm{p}<0.01 ; * * \mathrm{p}<0.05 ; * \mathrm{p}<0.10$

\section{Psychographic Factors and Perceived Service Quality}

To test the hypothesis pertaining to the psychographic factors $(\mathrm{H} 3)$, sub-hypotheses were developed. They are: H3a for activity, H3b for interest and H3c for opinion. Thus, the main hypothesis regarding the psychographic factor and its sub-hypotheses were as follows:

Hypothesis 3: There is a positive relationship between psychographic factors and perceived service quality.

H3a: There is a positive relationship between activities and perceived service quality.

H3b: There is a positive relationship between interests and perceived service quality.

H3c: There is a positive relationship between opinions and perceived service quality.

To test the hypotheses, multiple regressions were conducted. Table 4.3 displayed the result of the analysis which found that all of the sub-hypotheses were not supported. Overall, the main hypothesis (H3) appears not to be supported.

In sum, the results showed that the antecedents identified in hypotheses $\mathrm{H} 1, \mathrm{H} 2$, and $\mathrm{H} 3 \mathrm{Had}$ a partial impact on perceived service quality as some of the sub-hypotheses were found to be 
supported while others were not.

Table 3

Effect of Psychographic Variables on Perceived Service Quality

\begin{tabular}{clccc}
\hline Hypotheses & Variables & Standardized & t value & p value \\
& & coefficients & & \\
& & & & \\
& & beta & & \\
\hline H3a & Activity & -0.025 & -.147 & .883 \\
H3b & Interest & -0.033 & -.193 & .847 \\
H3c & Opinion & 0.124 & .676 & .499 \\
& R Square & & & 0.05 \\
& Adjusted R Square & & & 0.022 \\
& F Value & & & 1.821 \\
& F Value Sig & & 0.049 \\
& Durbin-Watson & & 2.100 \\
\hline
\end{tabular}

$* * * \mathrm{p}<0.01 ; * * \mathrm{p}<0.05 ; * \mathrm{p}<0.10$

\section{Discussion on the Results}

It can be seen from the table that six demographic factors and their impact on service quality have been investigated in the present study. These six factors include gender, age marital status, and level of education, monthly earnings, and finally family size. The findings revealed that age, monthly income and family size had significant influence on service quality while gender, marital status and educational level did not have any significant influence. Specifically, age and income were found to be positively related to service quality but family size was found to have a negative relationship. With regards to age, the majority of the respondents were relatively young (less than 44 years). Younger groups tend to follow purchasing trends more than their elderly counterparts and thus they have more favourable perception of service quality in terms of physical aspect for example and responsiveness.

With respect to income, the Saudi people are considered to be relatively well-off. One could argue that the better-off a person is, the more demanding he/she becomes and also the more likely he/she would compare between services from different service providers. Besides, 
Saudis tend to travel regularly to other countries and their travelling trips involve shopping activities and thus they compare and in turn they will have more favourable perception of service quality. For the family size, the findings revealed that this factor is related to perceive service quality in which the more family members there are the less likely their perceived service quality of the retailers. This is because families with many members tend to have numerous needs and the complexity of the needs resulted towards a lower perception of the service received from retailers.

The non-significant influence of gender, education, and marital status can be explained as follows. As far as gender is concerned, a significant number of the respondents were males who form $91 \%$ of the sample. Thus, that explains the non-significant relationship between gender and perceived service quality. The same applies to marital status in which most of the respondents were married. In Saudi Arabia, single people do not normally do their grocery shopping since they live with their parents who would do the grocery shopping on their behalf. Finally, the non-vital connection between the level of education and the perception about service quality in grocery shopping was also reported in prior research studies (Sinha\& Banerjee, 2004).

Similarly with reference to geographic factors Karlsson (2012) found that the nearer the customers to a particular retail outlet, the higher the tendency for customers to buy from that outlet; on the other hand, as the distances between the customers and the shop increases, the more choices the consumer has and it is less likely that the consumer would patronize the shop that is far from his/her residential location. Moreover, it was revealed from past studies that the time it takes to go to the store is a reflection of the total effort, both physical and psychological to arrive at the retail store. 'Accessibility' or location vicinity of a retail store site measures the level of comfort with reference to the shopping trip and, hence, symbolizes a major attribute of a retail store selection from a customer's perspective (Alzubaidi et al., 1997; Manu, 2011).

With reference to psychographic factors, previous studies have segmented customers according to the quality they perceive and their life styles (Huang, 2014; Kotler\& Keller, 2009), behaviours, pastimes, and views (Hassan et al., 2010). Cosmos (1982) revealed in his study that total variety of products and the service requested by customers was a reflective of their lifestyles using AIO (activities, interests, and opinions) factors. Krishnan (2011) revealed in their study conducted in USA that the psychographic factors (activities, interests, and opinions) influenced the perception of service quality of retail outlets. However, these factors were unable to significantly influence the service quality regarded by Saudi shoppers. This finding could be explained by the fact that a significant number of the respondents in this study were men who may not have much interest in shopping activity. Perhaps these factors are more related the nature of the character of the individual and could be related to other shopping activities and not in grocery shopping (Jay \& Sirgy, 2003).

With reference to psychographic factors, previous studies have segmented customers according to their perceived service quality of the retail outlets and their life styles (Huang, 2014; Kotler\& Keller, 2009) dimensions: activities, interests, and opinions (Hassan et al., 
2010). Cosmos (1982) revealed in his study that the total variety of goods and a service utilised by a customer was a reflective of the individual's way of life using AIO (activities, interests, and opinions) factors. Krishnan (2011) revealed in their study conducted in USA that the psychographic factors (activities, interests, and opinions) influenced their views about the quality offered by any given retail outlets. In fact, these factors failed to achieve significant influence on the perceptions about service quality by Saudi shoppers. This finding could be explained by the fact that large proportions of the respondents were men who may not have much interest in shopping activity. Perhaps these factors are more related to the nature of the character of the individual and could be related to other shopping activities and not in grocery shopping (Jay \& Sirgy, 2003). Another plausible reason could be the instrument measuring the psychographics itself. The Americans have designed the vast majority of these concepts and measures and the measurement items may not necessarily be cross-culturally applicable (Gorn 1997; Wong, Rindfleisch, Burroughs, \& Steenkamp, 2003). Parameswaran and Yaprak (1987) have stated that the same instrument used in a cross-national survey may lead to different levels of response reliabilities among various country samples due to difference in knowledge, perceptions, familiarity with research instrument and the national propensity to certain response style.

\section{Conclusion}

This study is an attempt to fill the gap in literature review and comes out by working on recommendations of the latest previous studies. Cross-sectional data consisting on 408 customers was collected from major shopping malls (Hyper Panda, Carrefour, Tamimi, Othaim, and Danube) located in three cities (Riyadh, Jeddah and Dammam) of Saudi Arabia. Multiple regression was used for analysis. The demographic factors (gender, marital status, age, education, family members, and income) significantly influence the provision of service quality perceived by the shoppers in the Saudi grocery retail market. The geographical factors (distance and ease of travel) significantly influence the provision of service quality perceived by the shoppers in the Saudi grocery retail market. The psychographic factors (activity, interest, and opinion) significantly influence the provision of service quality perceived by the shoppers in the Saudi grocery retail market.This study contributes in different aspects like, theoretical, practical, policy making, cross-culture understanding and managerial aspect. This study recommends that in future researchers should concentrate on examining consumers' desired value and their perceptions of other forms of retail stores such as specialty outlets or online stores that are becoming very prominent for today's consumers. This research also recommends that future researcher should focus on research in market sector as Saudi Arabia is not well explored by research. Implementing researches of overall Middle East on Saudi Arabia is like taking risk to implement in Saudi because Saudi have different culture and Islamic practices compare to other Arab countries so the findings can be different.

\section{References:}

Ahmad, A. E. (2012). Attractiveness Factors Influencing Shoppers' Satisfaction, Loyalty, andWord of Mouth: An Empirical Investigation of Saudi Arabia Shopping Malls. International Journal of Business Administration, 3(6), 58-67. 
Anderson., Eugene., \&ClaesFornell. (1994). A Customer Satisfaction Research Prospectus. 41-268 in R. T. Rust and R. L. Oliver (Eds.) Service Quality: New Directions in Theory and Practice. Thousand Oaks, CA: Sage Publications.

AlGhamdi, Rayed., Drew, Steve .,\&AlGhaith, Waleed. (2011). Factors Influencing E-Commerce Adoption by Retailers In Saudi Arabia: A Qualitative Analysis. The Electronic Journal on Information Systems in Developing Countries, 47(7), 1-23.

Al Rajhi Capital. (2013). Saudi Retail Sector. Retrieved March, 15, 2013 from http://www.aljaziracapital.com.sa/report_file/ess/SEC-34.pdf

Bagozzi, R. P. (1992). The Self-regulation of Attitudes, Intentions and Behavior.Social Psychology Quarterly, 55(1992), 178-204.

Balaji, M. (2009).Customer Satisfaction with Indian Mobile Services.IUP Journal of Management Research, 8(10), 52-62.

Baron, R. M., \& Kenny, D. A. (1986). The moderator-mediator variable distinction in social psychological research: Conceptual strategic and statistical considerations. Journal of Personality and Social Psychology, 51(6), 1173-1182.

Beerli, A., Martin, J. D., \& Quintana, A. (2004).A model of customer sense of fulfillment in the retail banking market.European Journal of Marketing. 38(1/2), 253-275.

Berry, L.L. (2000). Cultivating service brand equity. Journal of the Academy of Marketing Science, 28(1), 128-137.

Bedi, M. (2010). An integrated framework for service quality, customer satisfaction and behavioural responses in Indian Banking industry, a comparison of public and private sector banks. Journal of Services Research, 10(1), 157-172.

Bei, L.T., \&Chiao, Y.C. (2001). An integrated model for the effects of perceived product, perceived service quality, and perceived price fairness on consumer satisfaction and loyalty. Journal of Consumer Satisfaction, Dissatisfaction, and Complaining Behavior, 14, 125-140.

Biong, H, (1993). Satisfaction and loyalty to suppliers within the grocery trade.European Journal of Marketing, 27, 21-38.

Bryman, A., \& Bell, E. (2003).Business Research Methods.New York: Oxford University.

Bitner, M. (1990). Evaluating service encounters: the effects of physical surroundings and employee responses. Journal of Marketing.54(2), 69.

Bolton, R.N., \& Drew, J.H. (1991).A multistage model of customers' assessments of service quality and value.Journal of consumer research, 17(4), 375-384.

Boulding, W., Kalra, A., Staelin.,\& R., and Zeithaml, V.A. (1993). A dynamic process model of service quality: from expectations to behavioral intentions. Journal of marketing research, 30(1), 7-27.

Brady, M. K., \& Robertson, C. J. (2001).Searching for a consensus on the antecedent role of 
service quality and satisfaction: An exploratory cross-national study.Journal of Business Research, 51(1), 53-60.

Caruana Albert., Arthur H. Money., \& Pierre R. Berthon. (2000). Service quality and satisfaction - the moderating role of value.European Journal of Marketing, 34(11/12), $1338-1352$.

Chenet, P., Tynan, C., \&Mondy, A. (1999). Service performance gap: reevaluation and redevelopment. Journal of Business Research, 46, 133-147.

Cronin Jr, J.J., \& Taylor, S.A. (1992).Measuring service quality: a reexamination and extension.The journal of marketing, 56(3)55-68.

Cronin Jr, J.J., Brady, M.K., \&Hult, G.T.M. (2000).Assessing the effects of quality, value and customer satisfaction on consumer behavioral intentions in service environments. Journal of retailing, 76(2), 193-218.

Dabholkar, P. A. (1995). A contingency framework for perceiveddicting causality between customer satisfaction and service quality.Advances in Consumer Research, 22(1), 101-108.

Donnelly, M. (2009). Building customer sense of fulfillment: A customer experience based approach in a tourism context. Bachelor of Business Studies in Marketing, (June), 205-212.

Donthu, N., \&Yoo, B. (1998). Cultural influences on service quality expectations, Journal of Service Research, 1(2), 178-186.

Faullant, R., Matzler, K., \&Füller, J. (2008). The impact of satisfaction and image on loyalty: the case of Alpine ski resorts. Managing Service Quality, 18(2), 163-178.

Fornell, Claes. (1992). A National Customer Satisfaction Barometer: The Swedish Experience. Journal of Marketing, 56, 1-18.

Fullerton, G. (2005a). The impact of brand commitment on loyalty to retail service brands.Canadian Journal of Administrative Sciences, 22(2), 97-110.

Fullerton, G. (2005b). The service quality-loyalty relationship in retail services: does commitment matter? Journal of Retailing and Consumer Services, 12(2), 99-111.

Ganesan-Lim, Cheryl., Russell-Bennett, Rebekah., \& Dagger, Tracey. (2008). The impact of service contact type and demographic characteristics on service quality perceptions. Journal of Services Marketing, 22(7), 550-561.

Gutman, J. (1982). A means-end chain model based on consumers' categorization process. Journal of Marketing, 46(spring), 60-72.

Harris, Lloyd C., \& Goode, Mark M.H. (2004). The four levels of loyalty and the pivotal role of trust: a study of online service dynamics. Journal of Retailing, 80(2), 139-158.

Hallowell, R. (1996). The relationships of customer satisfaction, customer sense of fulfillment and profitability: an empirical study. International Journal of Service Industry Management, 7(4), 27-42. 


\section{Macrothink}

International Journal of Learning \& Development ISSN 2164-4063 2014, Vol. 4, No. 4

Hartman, K.B., \& Spiro, R.L., (2005). Recapturing store image in customer-based store equity: a construct conceptualization. Journal of Business Research,58(8), 1112-1120.

Hutchinson, J., Lai, F., \& Wang, Y. (2009).Understanding the relationships of quality, value, equity, satisfaction, and behavioral intentions among golf travelers. Tourism Management, 30(2), 298-308.

Imrie, Brian C.; Cadogan, John W., \& McNaughton, Rod. (2002). The service quality construct on a global stage. Managing Service Quality, 12(1), 10-18.In: Journal of Business \& Industrial Marketing 24(1): 3-13. In: Journal of Consumer Marketing 26(6): 392-402.

Kassim, N., \& Abdullah, N. A. (2010). The effect of perceived service quality dimensions on customer satisfaction, trust, and loyalty in e-commerce settings: A cross cultural analysis. Asia Pacific Journal of Marketing and Logistics, 22(3), 351-371.

Kim, S. H. (2011). Antecedents of Destination Loyalty. University of Florida, . Retrieved March, 1, 2011 from:

Kumar, M., Kee, F. T., \& Charles, V. (2010). Comparative evaluation of critical factors in delivering service quality of banks: An application of dominance analysis in modified SERVQUAL model. International Journal of Quality and Reliability Management, 27(3), 351-377.

Oliver, R. L. (1999). Whence consumer loyalty? Journal of Marketing, 63(Special Issue), $33-44$.

Magi \&Julander, 2009; Yeunget al., 2002; Luo and Homburg, 2007

Mohammad., Tabriz., Chalous., \& Aras. (2013). The effect of customer satisfaction on word of mouth communication. Research Journal of Applied Sciences, Engineering and Technology, 5(8), 2569-2575.

Mousa, H. (2012). Global Agricultural Information Network.In SA1217 (Ed.), Exporter Guide.Riyadh public distribution.

Mohammad., Tabriz., Chalous., \& Aras. (2013). The effect of customer satisfaction on word of mouth communication. Research Journal of Applied Sciences, Engineering and Technology, 5(8), 2569-2575.

Mustafa. (2011). Determinants of e-commerce customer satisfaction, trust, and loyalty in saudiarabia. Journal of Electronic Commerce Research, 12(1), 78-89.

Naeem, H., \&Saif, I. (2009). Service Quality and its impact on Customer Satisfaction: empirical

evidence from the Pakistani banking sector. The International Business and Economics Research Journal, 8(12), 99.

Oliver, R. L. (1999). Whence consumer loyalty? Journal of Marketing, 63(Special Issue), 33-44. 


\section{$\triangle$ Macrothink}

International Journal of Learning \& Development

ISSN 2164-4063

Olshavsky, R. W., \& Miller, J. A. (1972).Consumer Expectations, Product Performance and Perceived Product Quality.Journal of Marketing Research, 9, 19-21.

Ouroussoff, N. (2010). Saudi Urban Projects Are a Window to Modernity. Critic's Notebook, The New York Times. Retrieved January, 7, 2010 from www.nytimes.com/2010/12/13/arts/design/13desert.html?pagewanted=alland_r=0

Othaim, A. (2012). Al Othaim Hypermarket. Al Riyadh News Paper (15859).

Patterson P.G.,\&Spreng R.A. (1997). Modelling the relationship between perceived value, satisfaction and repurchase intentions in a business-to-business, services context: an empirical examination.International Journal of Service Industry Management, 8(5), 414-434.

Rahman, M. S. (2012). Service quality, corporate image and customer's satisfaction towards customers perception: an exploratory study on telecom customersinbangladesh. Business Intelligence Journal, 5(1).

Reynolds, Kristy E., \& Arnold, Mark J. (2000). Customer sense of fulfillment to the salesperson and the store: examining relationship customers in an upscale retail context. Journal of Personal Selling and Sales Management, 15(2), 89-98

Reynolds, T.J., \&Gutman, J. (1988).Laddering theory, method, analysis, and interperceivedtation.Journal of Advertising Research, 28(1), 11-31.

Rust., Zahorik., \&Keiningham, T. L. (1996). Service Marketing.New York, NY: Harper Collins.

Sasikala. (2013). Impact of demographics on service quality, customer satisfaction and loyalty in the indian banking in vellore district. Asia Pacific Journal of Marketing and Management Review,2(6), 102-112.

Srinivasan, Anderson., \& Kishore Ponnavolu, (2002). Customer sense of fulfillment in e-commerce: an exploration of its antecedents and consequences. Journal of Retailing 78 , $41-50$.

Taylor S.A.,\& Baker TL. (1994). An assessment of the relationship between service quality and customer satisfaction in the formation of consumers' purchase intentions. Journal of Retailing,70(2), $163-78$.

Taylor, S. A., \& Cronin, J. J. (1994).Modelling patient satisfaction and service quality.Journal of Health Care Marketing, 14(1), 34-44.

Wallace, David W., Giese, Joan L., \& Johnson, Jean L. (2004).Customer retailer loyalty in the context of multiple channel strategies.Journal of Retailing, 80(4), 249-263.

Winstanley, M., (1997). What dries customer's satisfaction in commercial banking Commercial? Leading Review, 12(3), 36-42.

Wong, A., \&Sohal, A.S. (2006).Understanding the quality of relationships in consumer services: A study in a retail environment.International Journal of Quality \& Reliability 
Management, 23(3), 244-264.

Woodruff, R.B. (1997). Customer value: The next source for competitive advantage. Journal of the Academy of Marketing Science. 25(2), 139-153.

Yang, K., \& Jolly, L.D. (2009). The effects of consumer perceived value and subjective norm on mobile data service adoption between American and Korean consumers. Journal of Retailing and Consumer Services. 16, 502-508.

Yee, R. W. Y., Yeung, A. C. L., \& Cheng, T. C. E. (2010).An empirical study of employee loyalty, service quality and firm performance in the service industry.International Journal of Production Economics, 124(1), 109-120. 